\title{
Smoking, alcohol consumption and oral cancer among healthcare academics
}

\author{
Tabagismo, etilismo e câncer bucal entre acadêmicos de saúde
}

Daniely Silveira SANTOS'

Roberta Alves Rosa dos REIS²

Letícia Antunes ATHAYDE ${ }^{3}$

Daniel Antunes FREITAS ${ }^{4}$

Árlen Almeida Duarte de SOUSA ${ }^{5}$

\section{ABSTRACT}

\section{Objective}

To evaluate if dental students with the habit of smoking exhibit alterations in the epithelial cells of the cheek mucosa on the nuclear area (NA), cytoplasmic area (CA) or in the nucleus/cytoplasm ratio (NA/CA), when compared to non-smokers.

\section{Methods}

This is a descriptive, experimental study using a control group. The sample comprised 40 dental undergraduates (20 smokers and 20 nonsmokers). Individuals who smoked at least 5 or 6 cigarettes a day were deemed to be smokers, while non-smokers were those who reported having no experience of any form of smoking. The samples of epithelial cells were obtained from the oral mucosa using the liquid-based exfoliative cytology technique. The slides were processed in the laboratory, stained using the Papanicolau technique and were analyzed via an image analysis system (analySIS getIT). A structured questionnaire was applied with the aim of measuring independent variables related to personal characteristics, health and lifestyle behavior.

\section{Results}

The values obtained in the group of smokers were as follows: NA (169.4 $\left.\mu \mathrm{m}^{2} \pm 17.0\right)$, CA $\left(1240.1 \mu \mathrm{m}^{2} \pm 128.9\right)$ and NA/CA ratio (0.1375 \pm $0.01743)$. The results did not evidence significant differences when compared to the control group: NA (170.7 $\left.\mu m^{2} \pm 20.0\right), C A\left(1255.3 \mu m^{2}\right.$ $\pm 174.5)$ and NA/CA (0.1380 \pm 0.01436$)$.

\section{Conclusion}

It was not possible to observe significant cell alterations in the NA, CA or the NA/CA ratio of epithelial cells of the oral mucosa. Other risk factors associated with tobacco should be studied, principally the length of exposure to the properties of the causative agent.

Indexing terms: Cytology. Oral neoplasia. Smoking habit.

\section{RESUMO}

\section{Objetivo}

Avaliar se os estudantes de odontologia que possuem hábitos tabagistas apresentam alterações celulares nas células epiteliais da mucosa jugal sobre as áreas nucleares (AN), citoplasmáticas (AC) e na relação núcleo/citoplasma (AN/AC) quando comparados a não fumantes.

\section{Métodos}

Trata-se de um estudo experimental, descritivo com grupo controle. A amostra foi composta por 40 estudantes de graduação em odontologia (20 fumantes e 20 não fumantes). Consideraram-se fumantes aqueles indivíduos que fumavam diariamente, no mínimo, cinco a seis cigarros do tipo industrializado; e não fumantes aqueles indivíduos que relataram a não experiência com qualquer tipo de fumo. As amostras de células epiteliais foram obtidas da mucosa oral pela técnica de citologia esfoliativa em meio líquido. As lâminas foram processadas em laboratório, coradas pela técnica de Papanicolau e analisadas através de um sistema de análise de imagens (Analysis get/t). Um questionário estruturado foi aplicado com o intuito de mensurar variáveis independentes referentes às características pessoais, comportamentos em saúde e estilo de vida.

\section{Resultados}

Os valores obtidos no grupo dos fumantes para a AN $\left(169,4 \mu m^{2} \pm 17,0\right)$, AC $\left(1240,1 \mu m^{2} \pm 128,9\right)$ e na relação AN/AC $(0,1375 \pm 0,01743)$ não apresentaram resultados com diferenças expressivas quando comparados ao grupo controle AN $\left(170,7 \mu m^{2} \pm 20,0\right)$, AC $\left(1255,3 \mu m^{2} \pm\right.$ $174,5)$ e na AN/AC $(0,1380 \pm 0,01436)$.

\section{Conclusão}

Não foi possível observar alterações celulares significantes nas AN, AC e na relação AN/AC de células epiteliais da mucosa oral. Outros fatores de risco associados ao tabaco devem ser estudados, principalmente o tempo de exposição às propriedades do agente causador.

Termos de indexação: Citologia. Neoplasias bucais. Hábito de fumar.

\footnotetext{
1 Universidade Estadual de Montes Claros, Residência Multiprofissional em Saúde da Família. Campus Universitário Professor Darcy Ribeiro, Vila Mauricéia, 39401-089, Montes Claros, MG, Brasil. Correspondência para / Correspondence to: SS SANTOS. E-mail: <danisilveira16@hotmail.com>.

2 Prefeitura Municipal de Montes Claros. Montes Claros, MG, Brasil.

${ }^{3}$ Faculdades Unidas do Norte de Minas, Centro de Pesquisa. Montes Claros, MG, Brasil.

${ }^{4}$ Universidade Estadual de Montes Claros, Departamento de Medicina. Montes Claros, MG, Brasil.

${ }^{5}$ Universidade Estadual de Montes Claros, Departamento de Métodos e Técnicas Educacionais. Montes Claros, MG, Brasil.
} 


\section{INTRODUCTION}

Cancer is characterized as a grouping of over 100 different types of disease that have in common a disorderly growth of potentially aggressive abnormal cells ${ }^{1}$. Among the cases of cancer of the head and neck, $40 \%$ occur in the oral cavity ${ }^{2}$. The risk factors associated with this disease include habits such as smoking and alcohol consumption, as well as diet, poor oral hygiene, exposure to ultraviolet solar radiation and other issues related to infection by HPV, periodontitis, genetics, stress and depression ${ }^{1,3}$.

It is incontrovertible that the chemical composition of tobacco has a considerable impact on the development of cellular alterations that are transformed into a carcinogenic process, which explains why tobacco usage is the main cause of cancer in the world ${ }^{3-4}$. Current research shows that the oral carcinogenesis process develops as a result of an abnormal acceleration of basal epithelial cells, resulting in a high level of mitotic activity, smoking being the crucial agent in this process of acceleration. This cell replication is identified through the Tumor Suppressor Protein, leading to an interruption in the cell cycle and, as a consequence, to apoptosis 5 .

As a general rule, the habit of smoking starts when young. The reasons that lead them to develop the habit are manifold, ranging from factors such as current fads, where these youngsters use these artifacts to gain acceptance into particular social groups, and also psychological factors such as stress, depression and family conflict, where the cigarette is shown to reduce anxiety and tension. Oral cancer most frequently afflicts people over 35 years of age, however, studies have shown that tobacco-related cancers are linked to younger people, which underscores the need for an early offensive and undertake a scientific evaluation linked to these topics ${ }^{6-7}$.

The practice of smoking among health service professionals is the subject of increasing investigation as the role of these professionals is linked to the fight against smoking. However, what is of most concern to researchers is the increase of this practice in this group of professionals. Once inserted into society, these professionals must serve as an example to their patients and should be more responsible in terms of combating the practice. This commitment should be no less vehement among students in the area of health, as they are being made ready to promote practices that are beneficial to the health of the population?

Accordingly, the aim of this study is to evaluate if dental students who smoke have cellular alterations in the epithelial cells of the cheek mucosa on the nuclear area (NA), cytoplasmic area (CA) and on the nucleus to cytoplasm ratio (NA/CA).

\section{METHODS}

This is a descriptive, experimental study using a control group. The sample comprised students aged 18 and over from the dentistry course of a private university in the town of Montes Claros, in the Brazilian state of Minas Gerais. A survey was conducted among the students with the aim of finding out which individuals made use of tobacco, as a result of which the participants were divided into two groups: Smokers and Non-smokers. The first group comprised 20 academics randomly selected amongst the smokers (simple draw), and the second group consisted of 20 academics amongst the non-smokers. The subjects were paired off by sex, age and use of alcoholic beverages.

Individuals were deemed to be smokers if they smoked at least five manufactured cigarettes a day (of those students who reported having the smoking habit, the lowest frequency was 5 cigarettes a day), and non-smokers were those who reported having had no experience of any form of smoking.

A structured questionnaire was applied with the aim of measuring independent variables related to personal characteristics (age, sex, self-declared skin color, course semester), health behavior (existence of any health-related problems, the use of continuous medication, family history of cancer, oral hygiene) and lifestyle (use of alcoholic beverages, the reasons leading to the habit of alcohol consumption, length of time since he/she took up drinking, the age he/she started drinking). The questionnaire was applied in the form of an interview, in a private room to maintain the participant's privacy.

For the collection of biological material, the procedures advocated by Batista et al. ${ }^{8}$ were adopted. The participants were instructed to rinse their mouth with water to remove possible food remains. A sample of epithelial cells was then obtained from the clinically healthy cheek mucosa, using the technique of liquid-based exfoliative cytology. The collection of cells was carried out with a sterile, cervical brush belonging to the KOLPLAST ${ }^{\circledR}$ system manufactured in Brazil.

The material was processed in the laboratory in accordance with the manufacturer's specifications, arranged on glass slides and fixed by immersion in a 
solution of $70 \%$ ethyl alcohol, for 20 minutes. They were then stained using the Papanicolau technique, which was followed by a cytomorphometric analysis.

An analysis of the swabs was carried out by way of a light microscope using a CX31 binocular microscope (Olympus, Japan), adapted with a WH 10X-HI22 eyepiece (Olympus, Japan) and PLAN 40X10.25 lenses (Olympus, Japan). Prior to taking the reading, the identification numbers of the slides were covered up to avoid the examiner being able to identify the individuals in each group. The initial epithelial cells from each slide that were presented in an elongated, isolated form, were studied by a single examiner. The nuclear and cytoplasmic areas were obtained by demarcating the nucleus and cytoplasm borders of the cell using a digitizer cursor. The image of the cytological fields was captured at a magnification of 400x by an Olympus OSIS USB camera (Flex-Camera-7, Japan) and the evaluation of the cells was performed via the analySIS getIT image analysis system (Olympus, Japan), version 5.2 .

Version 17.0 for Windows of the Statistical Package for the Social Sciences (SPSS) ${ }^{\circledR}$ was used to analyze the data. For a comparison of the mean values obtained, the Student's t-test was employed. Values of $\leq 0.05$. were considered statistically significant.

The ethical principles of this study were in accordance with National Health Council Resolution no. 466/12, approved by the Research Ethics Committee of the Educational Association of Brazil (CEP-SOEBRAS, substantiated opinion no. 772.397). All participants signed a Free and Informed Consent form.

\section{RESULTS}

A total of 40 dental students participated in the study (20 smokers and 20 non-smokers) who were attending semesters 1 through 10 of the dentistry course. The age range of the students was 20 to 30 years (Mean: 23.8 years; SD -3.34 ) and the majority were males (90\%); as for the question of race/color, the participants selfdeclared as belonging to the black population (57.5\%) and were attending the final semesters of the course (57.5\%).

Table 1 shows the characteristics evaluated across the whole sample. It was found that $80 \%$ of the students developed the habit of drinking in order to have a better social life or through the influence of others, and $53.3 \%$ took up smoking over six years previously.
Table 1. Personal characteristics, health and lifestyle behavior of smokers and non-smokers among university students. Montes Claros (MG), 2014.

\begin{tabular}{lcc}
\hline Variables & $\mathrm{n}$ & $\%$ \\
\hline Health problems? & & \\
No & 39 & 97.5 \\
Yes & 1 & 2.5
\end{tabular}

\section{Continuous use of medication?}

No

Yes

5.0

Instances of cancer in the family?

No $\quad 19 \quad 47.5$

$\begin{array}{lll}\text { Yes } & 21 & 52.5\end{array}$

Use of alcoholic beverages?

$\begin{array}{lll}\text { No } & 10 & 25.0\end{array}$

$\begin{array}{lll}\text { Yes } & 30 & 75.0\end{array}$

Reason for taking up drinking*

Social

Curiosity

50.0

Influenced by others

20.0

Length of time drinking alcoholic beverages*

Six years

46.7

Over six years

Started drinking aged *

Under 16

42.3

Over 16

Oral hygiene

$\begin{array}{lll}\text { Brush teeth three or more times a day } & 36 & 90.0\end{array}$

Brush teeth twice a day

10.0

\section{Use of dental floss}

$\begin{array}{lll}\text { Yes } & 30 & 75.0\end{array}$

$\begin{array}{lll}\text { No } & 10 & 25.0\end{array}$

\section{Use of mouthwash}

$\begin{array}{lll}\text { No } & 33 & 82.5\end{array}$

$\begin{array}{lll}\text { Yes } & 7 & 17.5\end{array}$

Using mouthwash for how long*

$\begin{array}{lll}\text { For three years } & 4 & 50.0\end{array}$

For over three years $\quad 4 \quad 50.0$

\section{Frequency of use of mouthwash*}

Every day $\quad 7 \quad 87.5$

Sometimes

* Number of respondents less than the number of participants. Source: Data collected by authors. 2014. 
Table 2 shows the characteristics evaluated in the case study group. It was found that $60 \%$ of the undergraduates developed the habit of smoking to feel more socially included or were encouraged to do so by other smokers and that 50\% took up the practice over six years previously. Moreover, another variable that makes this situation all the more serious is the link between smoking and drinking, observed in $75 \%$ of the students.

Table 2. Characteristics of smokers with regard to history of cancer and smoking and drinking habits. Montes Claros (MG), 2014.

\begin{tabular}{lcc}
\hline Variables & $\mathrm{n}$ & $\%$ \\
\hline Instances of cancer in the family & & \\
No & 10 & 50.0 \\
Yes & 10 & 50.0
\end{tabular}

\section{Reason for developing habit of smoking}

Social

Curiosity

Influenced by others

\section{Smoker for how long?}

Six years

Over six years

\section{Took up smoking at age}

12 to 15

Over 15

\section{Number of cigarettes smoked per day}

5 to 6

More than 6

\section{Use of alcoholic beverages?}

No

Yes

\section{Reason for taking up drinking*}

Social

Curiosity

Influenced by others

\section{Length of time drinking alcoholic beverages*}

\section{Six years}

Over six years

\section{Started drinking aged*}

\begin{tabular}{lll} 
Under 16 & 8 & 61.5 \\
Over 16 & 5 & 38.5 \\
\hline
\end{tabular}

Note: * Number of respondents less than the number of participants.
Table 3 demonstrates the cytomorphometric characteristics evaluated in the study. The Student's t-test showed there was no statistically significant difference between the groups with regard to the nuclear or cytoplasmic areas or the nucleus/cytoplasm ratio ( $p>0.05$ ).

Table 3. Mean of NA, CA and NA/CA for smokers and non-smokers. Montes Claros (MG), 2014.

\begin{tabular}{lccc}
\hline Variables & $\begin{array}{c}\text { Smokers } \\
\text { Mean } \pm \text { std. } \\
\text { deviation }\end{array}$ & $\begin{array}{c}\text { Non-smokers } \\
\text { Mean } \pm \text { std. } \\
\text { deviation }\end{array}$ & $\begin{array}{c}\mathrm{p} \\
\text { Value }\end{array}$ \\
\hline NA & $169.4 \mu \mathrm{m}^{2} \pm 17.0$ & $170.7 \mu \mathrm{m}^{2} \pm 20.0$ & 0.822 \\
CA & $1240.1 \mu \mathrm{m}^{2} \pm 128.9$ & $1255.3 \mu \mathrm{m}^{2} \pm 174.5$ & 0.757 \\
NA/CA & $0.1375 \pm 0.01743$ & $0.1380 \pm 0.01436$ & 0.922 \\
\hline
\end{tabular}

Note: NA: nuclear areas. CA: cytoplasmic areas. NA/CA: ratio of nuclear areas to cytoplasmic areas.

Figure 1 shows the microscopic views of the cells of the oral mucosa in swabs stained using the Papanicolau method, in academics who smoke (figure at left) and those who do not smoke (figure at right).

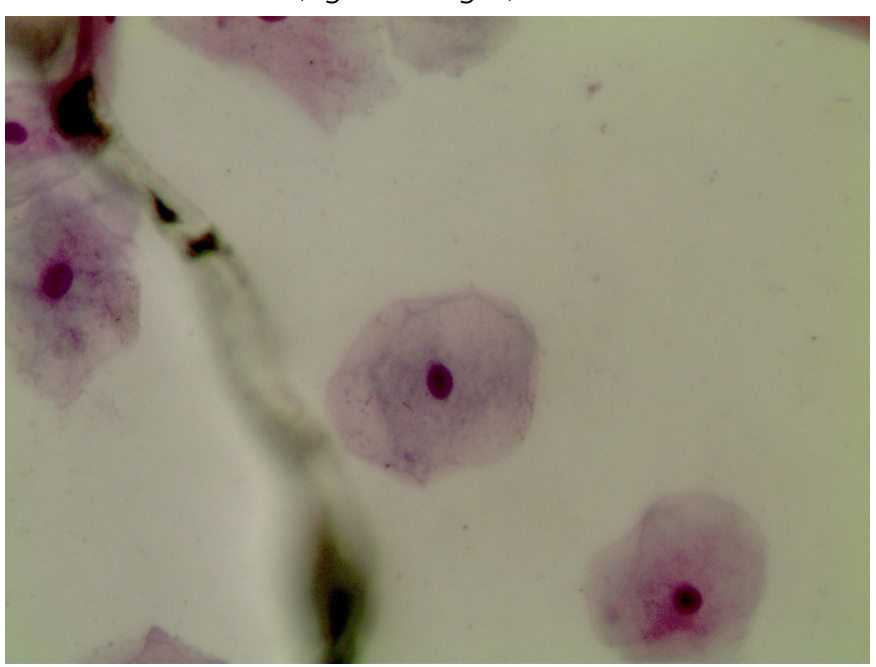

Figure 1. Cell from the Smokers group. Montes Claros (MG), 2014.

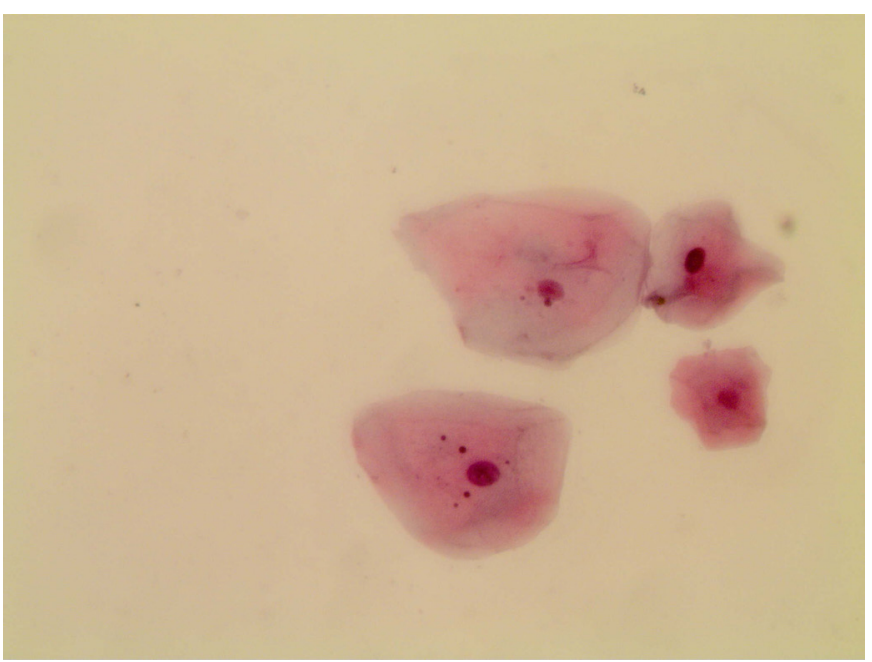

Figura 2. Cell from the Non-Smoker group. Montes Claros (MG), 2014.2014. 


\section{DISCUSSION}

A study carried out in Brazil based on a telephone survey, showed a reduction in the practice of smoking. This study, conducted in 2009, identified a frequency of smokers of $15.5 \%$ (males $19.0 \%$ and females 12.5\%). However, in 2013, prevalence had fallen to $11.3 \%$ (males $14.4 \%$ and females $8.6 \%)^{9}$. This reduction may be related to actions promoted by the Brazilian National Cancer Institute and the implementation of anti-smoking laws in the country ${ }^{10}$. In the present study there was some difficulty in selecting students to make up the group of smokers, as the frequency of the smoking habit amongst academics was very small; this finding evidences a widespread sense of awareness, amongst students in the dentistry course, of the harm caused by this practice and particularly the social responsibility and commitment each future professional must embrace ${ }^{11}$. In addition, attention must be paid to the need to extend these actions to the teenage population, as they may acquire the habit of smoking before going to university ${ }^{12}$.

It is noticeable that, for social reasons, men have a greater propensity for factors that develop cancers, such as smoking and drinking alcohol. These problems were observed in this study since the vast majority of participants were men and indulged in the habits of smoking and drinking. This situation was corroborated in a study which noted a higher prevalence of risk factors such as tobacco and alcohol usage among men ${ }^{13}$. The principal varieties of cigarette include the manufactured type, straw cigarettes, electronic versions, flavored cigarettes, hookahs, pipes, cigars, with or without the use of a filter. However, the manufactured cigarette is the most commonly used type around the world, containing in excess of 60 carcinogenic substances $^{14}$.

It can be seen that the habit of smoking is heavily associated with alcohol consumption. One study that evaluated the use of tobacco and associated factors among students found a strong statistical link between the use of tobacco, drinking and illicit drugs ${ }^{11}$, however, this practice is not just associated with a university lifestyle, as the average starting age is far lower than the age of entrance to university ${ }^{11,15}$.

Through the cytomorphometric analyses conducted in this study, it was not possible to observe a statistically significant difference for NA, CA or the NA/CA ratio. However, other variables involving the use of tobacco should be studied, mainly factors related to the length of exposure to the properties of cigarettes ${ }^{16}$. Regardless of etiological factors, such as sex and age, they should be considered by addressing alterations in cell structure (NA, CA and NAVCA ratio) ${ }^{17}$.

Similarly, it was not possible to observe significant alterations in a similar study conducted with dental university students, smokers and non-smokers, in which it was concluded that the substances in manufactured cigarettes were insufficient to promote significant changes in NA, CA or in the NA/CA ratio ${ }^{8}$. On the other hand, one study in which a similar methodology was applied, using longer exposure times, found that the nuclei of cells in the oral mucosa of smokers were larger $(16.5 \%)$, when compared to non-smokers ${ }^{16}$, demonstrating the significant influence of the length of exposure to the etiological agent.

Despite the fact that this study did not identify significant cytomorphometric changes, systematic tobacco control policies should be maintained considering that smoking is the most significant etiological factor in the development of cancers, where the monitoring of cell behavior is a strong ally in the processes of prevention. Other risk factors associated with tobacco should be studied for a greater control of the variables that influence alterations in epithelial cells of the oral mucosa, mainly the length of exposure to the properties of the causative agent.

\section{CONCLUSION}

It was not possible to observe significant cellular alterations in the nuclear areas, cytoplasmic areas or in the nucleus/cytoplasm ratio of epithelial cells in the oral mucosa of young university student smokers, when compared to non-smokers.

\section{Collaborators}

DS SANTOS and RAR REIS, conception, design, interpretation of data and writing of the manuscript. LA ATHAYDE, data analysis and interpretation. DA FREITAS, revision and final approval of the version to be published. AAD SOUSA, data analysis and interpretation, writing of the manuscript, revision and final approval of the version to be published. 


\section{REFERENCES}

1. Instituto Nacional de Câncer. Estimativas de incidência do câncer no Brasil [página da Internet]. Rio de Janeiro: INCA; 2014 [citado 2014 nov 8]. Disponível em: <http://www.inca.gov.br/ estimativa/2014/>

2. Freitas DA, Caballero AD, Pereira MM, Oliveira SKM, Pinho e Silva G, Hernández CIV. Sequelas bucais da radioterapia de cabeça e pescoço. Rev CEFAC. 2011;13(6):1103-08.

3. Alves VTE, Silva $H A B$, Ferreira MS, Kajihara G, Fukushima $H$, Oliveira FS, Domaneschi C, Nunes FD, Holzhausen M. Oral cancer related aspects of interest in periodontics. Braz J Periodontol 2013;23(04):31-7.

4. Filho VW, Mirra AP, López RVM, Antunes LF. Tobacco smoking and cancer in Brazil: evidence and prospects. Rev Bras Epidemiol. 2010;13(2):175-87. doi: 10.1590/S1415-790X2010000200001

5. Eversole LR, Wysock GP, Sapp JP. Patologia bucomaxilofacial contemporânea. $2^{\circ}$ ed. Rio de Janeiro: Santos; 2012.

6. Silva PSL, Leão VML, Scarpel RD. Characterizing the population with mouth and oropharyngeal cancer, attended in the sector of head and neck in a referral hospital in Salvador City - BA. Rev CEFAC. 2009;11(3):441-47.

7. Botelho C, Silva AMP, Melo CD. Smoking among undergraduate health sciences students: prevalence and knowledge. J Bras Pneumol. 2011;37(3):360-66. doi: 10.1590/S180637132011000300013

8. Batista $A B$, Ferreira FM, Ignácio AS, Machado MAN, Lima AAS. Effect of smoking on the oral mucosa of young individuals: cytomorphometric analysis. Rev Bras Cancerol. 2008;54(1):5-10.

9. Vigilância de Fatores de Risco e Proteção para Doenças Crônicas por Inquérito Telefônico. VIGITEL Brasil 2013 [página na Internet]. Brasília: Ministério da Saúde; 2014 [citado 2016 Jul 20]. Disponível em: <http://biavati.files.wordpress.com/2014/05/ vigitel-2013.pdf>.

10. Filho FSL, Galduróz JCF, Noto AR, Nappo AS, Carlini EA, Nascimento $A O$, et al. Random sample survey on the prevalence of smoking in the major cities of Brazil. J Bras Pneumol. 2009;35(12):1204-1211.
11. Meil WM, LaPorte DJ, Mills JA, Sesti A, Collins SM, Stiver AG Sensation seeking and executive deficits in relation to alcohol, tobacco, and marijuana use frequency among university students: Value of ecologically based measures. Addict Behav. 2016;62:135-44. doi: 10.1016/j.addbeh.2016.06.014

12. Ramis TR, Milke Gl, Habeyche EC, Oliz MM, Azevedo MR, Hallal PC. Smoking and alcohol consumption among university students: prevalence and associated factors. Rev Bras Epidemiol. 2012;15(2):376-385. doi. 10.1590/S1415$790 \times 2012000200015$

13. Dubey AK, Gupta $U$, Jain S. Epidemiology of lung cancer and approaches for its prediction: a systematic review and analysis. Chin J Cancer. 2016; 35:71. doi: 10.1186/s40880-016-0135-x

14. Filho AVM, Melo WA, Parreira AR, Pereira EA, Silva PGG, Carneiro LC. Incidência de fumantes entre universitários. Estudos. 2012;39(1).

15. Andrade APA, Bernardo ACC, Viegas CAA, Ferreira DBL, Gomes TC, Sales MR. Prevalence and characteristics of smoking among youth attending the University of Brasilia in Brazil. J Bras Pneumol. 2006 Jan-Feb;32(1):23-8. doi: 10.1590/S180637132006000100007

16. Goregen M, Akgul HM, Gundogdu C. The cytomorphological analysis of buccal mucosa cells in smokers. J Nat Sci Biol Med. 2015;6(Suppl 1):S22-S24. doi: 10.4103/0976-9668.166055

17. Patel PV, Kumar S, Kumar V, Vidya GD. Quantitative cytomorphometric analysis of exfoliated normal gingival cells. J Cytol. J Cytol. 2011 Apr-Jun; 28(2): 66-72. doi: 10.4103/09709371.80745 